\title{
Work, Virtues, and Flourishing: A Special Issue from the EBEN 25th Annual Conference
}

\author{
Joan Fontrodona • Alejo José G. Sison
}

Received: 3 December 2013/Accepted: 15 January 2014/Published online: 15 February 2014

(C) Springer Science+Business Media Dordrecht 2014

\begin{abstract}
The paper is the introduction to a selection of papers submitted to the EBEN 25th Annual Conference which took place at IESE Business School in Barcelona from September 20 to 22, 2012. The text presents the rationale behind the program of the Conference, and summarizes the content of the selected papers.
\end{abstract}

Keywords Work - Virtue - Human flourishing - Personal development $\cdot$ Social development

"Work, Virtues, and Flourishing" was the theme selected for the EBEN 25th Annual Conference which took place at IESE Business School in Barcelona from September 20-22, 2012.

Reflecting on the concept of work is of great importance in itself as well as from the standpoint of its significant ethical component. Additionally, at the time the conference took place, there was the added circumstantial factor of an economic crisis that had destroyed many jobs. In this context, reflecting on work, aside from being an important question from a theoretical point of view, had also become an urgent issue from a practical point of view.

The importance of work - and its ethical dimensioncan be developed on different levels. On the individual level, as human beings we bring all of our qualities into play in our work: our theoretical knowledge, our technical

\footnotetext{
J. Fontrodona $(\bowtie)$

Business Ethics Department, IESE Business School, 08034 Barcelona, Spain

e-mail: jfontrodona@iese.edu
}

\author{
A. J. G. Sison \\ Philosophy Department, University of Navarra, \\ 31080 Pamplona, Spain \\ e-mail: ajsison@unav.es
}

abilities, our capacity for social relationships, as well as our personal values and moral principles. Not only do those qualities help us do our work better, but also through that work - and, in a much broader sense, through our actionswe build on those qualities and improve them. It is through our work that we become the person we are. From an ethical point of view, it is important to reflect on what kind of people we become based on our actions and decisions, and on how those actions and decisions reflect our way of being and our convictions.

On a second level, in most cases, our work takes place within an organizational and business context. We work together with others within a framework that is defined by a series of practices, policies, and objectives that constitute the organization's formal system, and a culture, a history, and behavioral customs that define the organization's informal system. This organizational context is not neutral with respect to the way in which we act. According to how it is defined, it will have a positive or negative impact on us: it can make it easier for us to act in accordance with our own convictions, allowing us to develop our capabilities; or, on the contrary, it can hamper that personal growth, placing us in conflicting situations in which we are asked to do things that go against our principles. Therefore, from an ethical point of view, it is also important to think about how we design organizations so as to allow for this personal growth among the people working in them. When it comes to business executives, it is also important to recognize that, based on their decisions, they influence the personal development of the people who are charged with executing those decisions.

On a third level, businesses are important agents of social development. Through our work, we contribute to improving the societies in which that work takes place. Work is an important factor in social development and in 
the generation of wealth. Businesses contribute to social development through the goods and services they offer; they also have an impact on society through their operations. We cannot be satisfied with the idea that businesses fulfill their social responsibilities by creating economic value, or by sharing that value equally among all of their stakeholders. Part of the reflection on ethics involves expanding the horizons of corporate social responsibility and questioning the paradigms that have served as the foundation for business theory up until now.

The subtheme of the EBEN 25th Annual Conference reflected these three levels: "Better People, Better Organizations, Better Societies." Work contributes to people's growth, to improvements in organizational design, and to social development.

Different general sessions took place during the conference, in which all of these aspects were discussed. The first session focused on the impact of work on our lives, reflecting on the meaning of work and its relation to happiness. A second session debated the context of the economic crisis and the need for creating conditions for a more sustainable labor market. A third session presented practical examples of different ways of understanding work, with contributions from entrepreneurs, NGOs and businesses that work toward social integration and fair trade.

More than a hundred contributions were received, which were presented in a number of parallel sessions and which contributed to the success of the conference. This special issue includes 10 papers that went through a selection and evaluation process following the conclusion of the conference. As a whole, this selection of papers offers a general perspective of the diverse themes touched on during the conference.

The first three papers present empirical evidence of the positive impact that attention to employees has in organizations. In "CSR Policies: Effects on Labor Productivity in Spanish Micro and Small Manufacturing Companies," Pablo Esteban-Sanchez and Sonia Benito-Hernández present the results of an empirical study among Spanish micro and small manufacturing companies, which shows how the internal dimensions of CSR, such as those concerning relationships with employees and responsibility in processes and product quality, can improve labor performance and labor efficiency. Pablo Ruiz Palomino Ricardo Martínez, Job Rodrigo, and Cristina Díaz, in "Level of Coherence Among Ethics Program Components and Its Impact on Ethical Intent," report the results of a study on ethics program components in the Spanish financial services industry and how the implementation of those policies has a different impact on the ethical intent of the employees. Finally, in "Workforce Diversity and Religiosity," Hoje Jo, Jinhua Cui, Haejung Na, and Manuel G. Velasquez used a large and extensive U.S. sample of firms from 1991-2010 to examine the empirical association between a firm's workforce diversity and the degree of religiosity of the firm's management. They conclude that religion is a factor that influences managers to more positively embrace workforce diversity.

The following four articles present a critical vision of a number of current paradigms and models and offer ways of introducing new elements into the reflection on work. Massimiliano Matteo Pellegrini and Cristiano Ciappei, in their paper titled "Ethical Judgment and Radical Business Changes: The Role of Entrepreneurial Perspicacity," offer an interpretative model for entrepreneurial judgment, in which the virtue of perspicacity, as the ability to judge exceptional cases correctly, plays an important role. In their paper "Virtue: The Missing Element in Emotional Intelligence," Michael John Segon and Chris Booth raise concern for the capacity of an unethical manager to fulfill emotional ethical competencies, based on the review of various versions of Emotional Intelligence frameworks. To address this concern, the authors propose the inclusion of an ethical foundation competency based on virtue ethics. Manuel Guillen, Ignacio Ferrero, and W. Michael Hoffman, in their paper "The Neglected Ethical and Spiritual Motivations in the Workplace," propose a new categorization of motivations that includes two new dimensions-ethical and spiritual-, which would improve management practices and foster greater human flourishing in the workplace. Finally, Geert Demuijnck, in his paper "Universal Values and Virtues in Management Versus Cross-Cultural Moral Relativism: An Educational Strategy to Clear the Ground for Business Ethics," attempts to clarify some confusions in which business people and students are often trapped regarding universal values and moral relativism, and proposes an educational strategy to overcome these philosophical confusions.

The final three papers focus on certain specific workrelated aspects. In "From Rationality to Emotionally Embedded Relations: Envy as a Signal of Power in Stakeholder Relations," Marjo Siltaoja and Merja Lahdesmaki reflect on the role that emotions play in the relationships between managers and their stakeholders, presenting the case of envy as a signal of asymmetrical power relations. Dan Nie, Master, and Anna-Maija Lämsä take on a crosscultural approach to their study on leader-member relationships. In their paper "The Leader-Member Exchange Theory in the Chinese Context and the Ethical Challenge of Guanxi," they examine the leader-member exchange theory in the context of Western expatriate managers and Chinese employees in China, as well as the social and moral norms of guanxi, a crucial element in the Chinese value system. Finally, François-Régis Alcide Puyou and Eric Faÿ, in their paper "Cogs in the Wheel or Spanners in the Works? A Phenomenological Approach to the Difficulty and Meaning of Ethical Work for Financial Controllers," draw 
on concepts from Michel Henry's phenomenology of life to explore the practices of management accountants. Based on Henry's suggestion that relying only on abstract representations constitutes a specific ideology that hinders ethics, they argue that the source of business ethics lies beyond professional standards, codes, and values.

As we present readers with this special issue, we would like to extend our thanks to the numerous scholars who served as anonymous reviewers. Their generous contribution has been a valuable aid in our work as guest-editors. We would also like to thank the editorial team at the Journal of Business Ethics for their support. And, finally, our thanks to everyone who contributed, in one form or another, to the organization and development of the EBEN 25th Annual Conference, a portion of the results of which are presented here. 